\begin{abstract}
Migrants who are privileged by citizenship, class or 'race' are largely still absent from mainstream migration research and theory; until recently they were generally assumed to be adaptable and acceptable cosmopolites, positive drivers of cross-border transfers of knowledge and skills. This has been addressed by an emerging scholarship on 'expatriates'. This article offers a review and critical reading of that literature; it considers the instabilities and ambiguities of the term 'expatriate' and situates expatriate migrants within the global economy, before examining the gendered nature of expatriation and attending to migrants' incorporation in host contexts and expatriate negotiations of identity. The literature suggests that at the heart of these processes lie complex configurations of racialisation, gender, class, and nationality, often involving problematic reproductions of the colonial past. This article argues that these issues are inherently related to the category's inconsistencies, rendering it difficult as a 'category of analysis'. Instead, rather than using the term as a pre-given conceptual frame, it needs to be treated as a 'category of practice' to be investigated in its own right. Especially as the subject becomes more established in migration studies, scholars need to reckon with the on-going challenge that lies in studying the identity category 'expatriate' while resisting reproducing a reified understanding of it.
\end{abstract}




\section{Privileged mobilities: locating the expatriate in migration scholarship}

Privileged instances of migration, especially flows originating in the Global North, only recently gained more visibility in migration studies (Leonard 2010a; Fechter \& Walsh 2010). The discipline largely focuses on migrants leaving poorer for more affluent regions, usually less privileged in their mobility; even research on skilled migrants generally focuses on flows to richer, industrialised countries. Not only have migrants who are privileged by citizenship, class or 'race' been largely absent from mainstream migration research and theory; where they made their way into scholarship, they shared their framing as drivers of cross-border transfers of knowledge and skills, a "small, invisible, adaptable uncontroversial segment of migration" (Knowles \& Harper 2010, p.7). These movements were assumed unproblematic to host societies and migrants themselves, who were considered to experience only minimal difficulties postmigration (ibid.). Migration studies here risks (re)producing a skewed image of migrants and immigrants as predominantly non-Western, non-white, non-elite subjects, while at the same time failing to take seriously the experiences of migrants that do not fit this image (cf. Croucher 2012). This has moral and political implications, as much as it has conceptual and theoretical consequences, resulting in incomplete and limited understandings of migration processes as a whole (Fechter \& Walsh 2010).

This has been addressed by an emerging literature on 'expatriates'. Research that explicitly looks at expatriates as migrants is a relatively recent phenomenon, with the majority of work published in the past 15 years (although, see Cohen (1977) for an early but largely overlooked article). Like migration studies generally, it is a diverse and interdisciplinary literature. It further overlaps with related work on 'privileged movement or migration' (Amit 2011; Croucher 2012), literatures on 'lifestyle' and 'international retirement migration' (O'Reilly 2000; King et al. 2000; Benson \& O’Reilly 2009; Benson 2014; Hayes 2014), intra-European mobile professionals (Favell 2008; Scott 2006), and 'middling 
migrants' in the UK (Conradson \& Latham 2005). Despite the term expatriate's instabilities and problematic connotations, its colloquial use is widespread (Fechter 2007; Leonard 2010a). The category remains central to many migrants' own discourses on identity - whether through its whole-hearted embrace or ardent rejection - and will likely stick around, as evidenced by the growing number of online forums geared towards 'expats' (Fechter 2007, 2012a). Research around expatriation also constitutes a burgeoning field within Human Resource Management, reflecting the notion's persistent significance in the business world (Harvey \& Moeller 2009). All the while, expatriation is seeing significant changes, partly related to companies' altering remuneration and compensation practices (ibid.; Fechter \& Walsh 2010). The concept's continuing if not growing prominence, its changing nature as much as its moral and political implications necessitate its continued critical study (Fechter \& Walsh 2010).

While migrants in diverse locations identify as expatriates, expatriate communities constitute especially visible, exclusive and self-conscious spatialities in the global South. Accordingly, scholarship has largely concentrated on Southern contexts, especially 'globalising cities', and that work is also the focus of this review (Fechter \& Walsh 2010; Lester 2012). As the article shows, the literature productively employs postcolonial perspectives in tracing remnants, reproductions but also rejections of Empire within expatriate settings. Already early work recognised the challenge that lies in studying the identity category expatriate while resisting reproducing a reified understanding of it (Fechter 20007). Navigating this tension remains crucial, especially as the topic becomes more established in migration studies. To do so, this article argues, it is useful to draw on Brubaker and Cooper's (2000) distinction between categories of analysis and practice. Rather than used as a scholarly 'category of analysis', the term expatriate needs to be conceived and treated as an everyday 'category of practice' to be investigated in its own right. Refraining from employing the expatriate as a category of analysis is necessary given the category's various ambiguities and uncertainties. These are intimately related to the intersecting workings of race, class, nationality and gender that lie at the heart of the category and often involve a problematic reproduction of the colonial past. 
Instead, it is argued, migration studies needs to inquire how the expatriate as a 'category of practice' emerges as a contingent product of various social, economic and political processes and institutions.

The remainder of this article will first trace the instabilities of the category 'expatriate', noting matters of power and privilege related to this definitional work. A second section will outline literature that situates the expatriate within the global economy, while a third part will focus on expatriate migration's gendered nature, followed by a fourth section discussing socio-cultural incorporation in host contexts. Against this backdrop, a last section will further discuss this paper's central argument that while the expatriate is problematic as a category of analysis, migration studies need to further critically investigate the category itself as the object of analysis. The paper will propose imperatives for further research along these lines.

\section{Mapping different readings of the expatriate}

Early work like Fechter (2007) already noted that 'expatriate' is a malleable and unstable term. The word has its roots in the Latin ex ('out') and patria ('native land'), literally referring to someone living outside of their native country (Klekowski von Koppenfels 2014). Yet, in contemporary usage the term has multiple co-existing and not necessarily congruent meanings and is difficult to delimit with any certitude. A first prominent understanding stems from Human Resource Management literature (Harvey \& Moeller 2009; Dabic et al. 2013). According to the Financial Times Lexicon (n.d.), an expatriate is an intracompany transfer, "an employee who is sent to live abroad for a defined time period". Similarly, especially earlier migration literature tended to equate the expatriate with the transnational professional or skilled migrant (see e.g. Beaverstock 2002). However, in general usage the term is taken to refer to a much wider range of people (Fechter 2007; Walsh 2010, 2014); it is at the same time broader (i.e. including unskilled migrants) and narrower (i.e. many highly skilled migrants are not called expatriates) than that of the skilled migrant (cf. Yeoh \& Willis 2005b; Meier 2015). The concept is at times used as an umbrella term; for instance Sriskandarajah and Drew (2006) denote all British citizens 
permanently residing abroad 'British expatriates'1. 'Expats' also often figure as sun-seeking, retiree communities in pursuit of a better life in warmer climates (O’Reilly 2000). Media representations, colloquial usage and actual expatriate communities commonly comprise both skilled and un-skilled migrants, who have moved with or without secure employment prospects or for outright nonprofessional reasons (Stone \& Stubbs 2007; Walsh 2010, 2014). Indeed, Green (2014) shows that expatriate communities always included diverse populations, pointing to US expatriates from all walks of live in early $20^{\text {th }}$ century France. Expatriates, like other migrants, often do not have a clear idea of when or whether they will return; some settle permanently in their host societies, while others continue to move between overseas destinations (Fechter 2007; Klekowski von Koppenfels 2014).

The meaning of the word expatriate has also changed substantially over time. 'To expatriate' originally comprised giving up one's citizenship and carried connotations of expulsion and exile (Green 2009). Quite differently, in the British context the term 'expatriate' is regularly employed in combination with 'colonial officer' in accounts of late colonial lives (Fechter 2007; Bickers 2010). Lester (2012) more specifically identifies 'Imperial Careerists' - the usually overlooked type of Imperialist, neither settler nor explorer - as the expatriate's closest colonial progenitor. This link with Imperial migrations further points to 'racial' and class biases haunting the contemporary 'expatriate'. Its etymology as well as expatriate migration's realities render it largely synonymous with the category 'immigrant'. The United Nations Department of Economic and Social Affairs (1998, p.10) defines the 'international long-term immigrant' as

A person who moves to a country other than that of his or her usual residence for a period of at least a year (12 months), so that the country of destination effectively becomes his or her new country of usual residence.

Yet, the terms immigrant and expatriate are hardly employed interchangeably in popular or even academic usage. As Leonard (2010a) and Fechter and Walsh

\footnotetext{
${ }^{1}$ They state that their "research suggests that around 5.5 million British nationals live overseas permanently (equivalent to 9.2 per cent of the UK's population). In addition, an estimated 500,000 British people live abroad for part of the year, mainly through second-home ownership" (p. viii).
} 
(2010) argue, the term expatriate is usually and intuitively reserved for 'Western' nationals who move abroad; that is to say, for (white) Western migrants. In contrast, citizens from less economically developed regions - who are not part of cosmopolitan elites - are typically termed immigrants or migrant workers (cf. Yeoh \& Willis 2005b).

Tellingly, expatriates are found to not self-identify as (im)migrants, and are unlikely to relate their own migration to that of less privileged migrants (Leinonen 2012; Croucher 2012). 'Western' migrants still profit from the global power relations established during European Empire and colonialism and often harbour attitudes that regard free international mobility as an unquestioned right of Europeans and their descendants (Leonard 2010b). Experiences of a 'new' migrant status (e.g. when this casual anticipation of free mobility is impeded) can prove unsettling, trigger negative emotional responses, and even find outlets in racialised discourses of the local other (Walsh 2010, 2012). Expatriate migrant identities are certainly constructed against and in relation to 'Others'. These 'Others' centrally include host country nationals, as discussed in the section on incorporation, and '"other migrants', who are differentiated by race, class, nationality, occupation and profession" and excluded by conceptual boundaries (Lundström 2014, p.6). In Dubai "the status distinction between various nationalities of migrants is taken for granted" and indeed carefully policed (Walsh 2014, p.7). British migrants' every day encounters with and discourses about relatively low skilled migrants from Asia and the Middle East can be seen as 'displaced postcolonial encounters' (Walsh 2010). In other words, expatriate British identities in Dubai are at least partly grounded in historical colonial relations enacted elsewhere and can involve Orientalising or racist discourses about less privileged and often non-white migrants (Walsh 2010, 2012; Rogaly \& Taylor 2010). What the extant literature reveals is that whilst there is considerable ambiguity around who is considered an expatriate, the category is firmly linked to the realities of global power relations and inequality. 


\section{Transient elites, class diversity and whiteness in the global}

\section{labour market}

Especially earlier migration scholarship often conceptualised expatriates as skilled migrants, particularly denoting hyper-mobile managerial elites holding key positions of power in the global economy (Findlay 1995; Findlay et al. 1996; van Bochove \& Engbersen 2013). Beaverstock $(2002,2005)$ argues that transient expatriates need to be understood as crucial actors in the current phase of global capitalism; bringing highly specific knowledge, skills and networks into the global and globalising cities they connect (cf. Findlay et al. 1996). Some have attempted to develop further typologies of these skilled migrants (Gould 1988 cited in Findlay 1995; Scott 2004,2006; Salt 1988), while Cranston (2014) argues for grounded ethnographic explorations of how expatriation not only drives, but is produced, 'performed into being' by the global economy. This work largely supports the thesis of a 'transient transnational elite', whose members move within a single global labour market. Beaverstock (2002) argues, that the lifestyles and practices of elite professionals constitute embedded 'spaces of flows', while they are simultaneously dis-embedded from local spheres. This is challenged by work, further discussed in the following sections, that argues for viewing transnational elite subjects as 'embodied beings', as bearers of culture who always "come to earth" in the contact zones where their trajectories intersect with those of other subjects (Yeoh \& Willis 2005a, p.281; cf. Lloyd 2010, Walsh 2012; Lloyd \& Hopkins 2015; Meier 2015).

The equation of the expatriate with the highly skilled migrant is further troubled by work that finds that expatriates do not necessarily conform to the image of mobile careerists performing 'elite functions' in the global economy (O'Reilly 2000; Farrer 2010; Leonard 2010c; Walsh 2010, 2014). Meier (2015) therefore distinguishes between 'migrant professionals' and 'expatriates', with the former explicitly including non-Western migrants. Cohen (1977) already observed that expatriates perform lower echelon jobs as secretaries or file clerks and Walsh (2010) confirms that Britons' occupations in Dubai increasingly include middleclass or even unskilled jobs in retail and tourism. Farrer (2010) encountered possibly as many 'refugees' from global capitalism as 'elite talents' in China, 
noting that class boundaries within expatriate settings can be pronounced and rigid. The diversity of expatriate labour and experiences is further exemplified by the case of 'expatriate aid workers', which has gained increasing attention partly due to the professionalisation of relief and development work (Hindman \& Fechter 2010; Fechter 2012ab, 2013). Yet, despite internal diversity and class divisions, as a 'migrant community' expatriates have retained a relatively privileged position in social and economic hierarchies, especially in countries of the global South (Walsh 2010).

Research on expatriates has also noted important parallels between the contemporary international, and previous Imperial labour markets. Decolonisation, while significant, often led to a reconfiguration of organisational practices and discourses and expatriates' professional identities, rather than an all-encompassing transformation (Kothari 2006; Redfield 2012). Leggett (2010) highlights continuing race-based segregation and hierarchies within expatriate working places in Jakarta, as colonial imaginations and subjectivities remain inscribed in organisations' very structures, and in particular underlie companies' hiring practices. Similarly, expatriates' "internationality" and "cultural origins" can be "the defining contribution which often explained their employment in Hong Kong in preference to local skilled staff' (Findlay et al. 1996, p.60). Leonard (2010abc) suggests that the globalised labour market offers disparate rewards based on personal characteristics like 'race', gender and citizenship. In this context, whiteness is not only a transferable resource but its value is often even reinforced through migration processes (cf. Lundström 2014). Privileges brought by whiteness are no longer, of course, automatic. Yet, 'race' likely operates with a special salience for expatriates as "whiteness and masculinity, conflated into the constitution of the 'skilled migrant', continue to be highly valued and remitted" in the globalising labour market (Leonard 2010b, p.508; cf. Walsh 2010). Indeed, work and its institutional organisation remain a key context in which forms of 'otherness' are articulated, lived and reproduced today (ibid.). 


\section{'Mobile professionals and trailing spouses'? Gender dynamics in expatriate migration}

Gender is a key dimension of expatriate migration, implicated in the very determinants and modes of migration, and fundamental to the organisation of expatriate communities and identities (Yeoh \& Khoo 1998; Yeoh \& Willis 2005b; Coles \& Fechter 2008). Research has primarily investigated how gender operates within heterosexual expatriate families and consistently found a persistence of traditional gender roles and family structures, irrespective of the host context or migrants' nationalities (Walsh 2006a, 2012). Amongst professional heterosexual couples, men are still predominantly the lead migrants and the performance of hegemonic migrant masculinities revolves around work and leisure, firmly located in the public sphere (Walsh 2006a, 2011). Coles and Fechter (2008) find that husbands' careers are often prioritised over those of their wives, which are put on hold or discontinued altogether. Women meanwhile adopt the infamous role of the 'trailing spouse', assumedly engaged in hedonistic, socialising and pleasure-seeking lifestyles. Fechter's (2007) ethnographic research on corporate expatriate wives in Jakarta shows that indeed, some women embrace the lifestyles associated with 'trailing spouses'. They are complicit, often active agents in the reproduction of conventional, patriarchal gender dynamics. Yet, Fechter (2007) also notes that many women feel trapped in a 'golden cage' that cannot compensate for the loss of their pre-migration, often professional lives, their reduced agency and the fact that their social status is now directly dependant on their husbands.

The reality of 'trailing spouses' is further complicated by findings of a highly gendered migration process, which structurally produces different sets of experiences for women and men (Yeoh \& Khoo 1998). Indeed, economic and institutional factors as well as administrative rules governing immigration often present hurdles to women's employment. Women are often automatically issued dependents' visas that do not allow paid work; similarly, transnational corporations have been found to insist on the female spouse's non-employment (Yeoh \& Khoo 1998; Fechter 2007; Lehmann 2014). While expatriate migration mainly represents a career move for men, women often experience a re- 
domestication and de-valorisation of their productive capabilities (Yeoh \& Willis 2005b). These outcomes are neither automatic nor generally welcomed by women, but the product of a "systemic institutionalisation of conventional gender roles within migration mechanisms and economic organisations" (Yeoh \& Khoo 1998, p.170).

The 'trailing spouse' discourse, much like earlier representations of colonial wives, also serves political functions (Fechter 2010). Contrary to dominant imaginations, women's domestic and emotional labour and especially their social activities can be essential for advancing their husbands' careers (Fechter 2007; Beaverstock 2002, 2005). If indirectly, both colonial wives and 'trailing spouses' actually perform crucial roles in the political projects they are involved in - be it Empire or global capitalism (Fechter 2010). As Fechter (2010) argues, vilifying these women can itself be understood as a discursive strategy within a division of ideological labour; assigning women the 'lion's share of moral responsibility' works to deflect attention from the larger asymmetrical systems of global power they are situated within and, more specifically, from their husbands' very real work in maintaining these systems.

Gender is undeniably fundamental to expatriate migration, yet there is considerably more diversity and nuance to the situation than apparent in the received story of male lead migrant and female trailing spouse. In a small yet growing number of cases husbands accompany women in their international career moves (Yeoh \& Khoo 1998; Cole 2012). Similarly, gender roles might not be as pronounced in non-corporate expatriate families. Stone and Stubbs (2007) for instance find women highly involved in expatriate self-employment in rural France. Moreover, migrant men (while not performing much actual housework) have been found to actively engage in producing homeliness in the domestic sphere (Walsh 2011). Still other work notes diverging experiences for single migrants (Walsh 2006ab; Willis \& Yeoh 2008; Fechter 2008), exploring for example performances of heterosexuality amongst single British expatriates in Dubai (Walsh 2007). Yet, while these trends complicate the picture, they often do not fully challenge entrenched unequal gender roles, identities and relations 
(Yeoh \& Khoo 1998; Cole 2012). Overall, few studies have shifted the gaze away from the heterosexually conceived nuclear family unit. Not only do sexuality and specifically hetero-normativity within immigration policies, organisational practices and everyday realities need to be addressed; it also has to be questioned "how implicit normative assumptions around family, heterosexual reproduction, and marriage" abound in migration literature itself (Manalansan 2006, p. 224; cf. Luibhéid 2004; Walsh 2011).

\section{Socio-cultural incorporation, expatriate identities and Empire}

Imperial and colonial histories are of on-going importance to expatriate migrants' incorporation and subjectivities in Southern host contexts. Like all migrants, expatriates integrate to varying degrees, partly depending on the context of reception (Klekowski von Koppenfels 2014; Harvey 2008). Inclusion is not a seamless process even for relatively privileged migrants, as they experience socio-psychological acculturation processes and can face stereotypes similar to other migrants (O’Reilly 2000; Leinonen 2012). Nevertheless, expatriate experiences of incorporation are unlike the exclusions and racisms that other migrants routinely face (Klekowski von Koppenfels 2014). Especially in poor countries, expatriates can integrate selectively according to their needs and tastes; many adopt more or less segregated transnational life-styles, largely unaffected by local customs and values (Beaverstock 2002; Fechter 2007; Coles \& Walsh 2010). Moreover, unlike most migrants, expatriates often gain rather than lose status upon migration (Walsh 2010; Lundström 2014). As Cohen (1977) observes, in many ex-colonial countries expatriates inherited a lofty elite status from their colonial predecessors, an ascribed status relatively independent of expatriates' particular roles.

As Lester (2012) argues, the majority of places contemporary expatriates inhabit are direct results of Empire, whose nodal points have become the 'globalising cities' that expanding capitalism relies on nowadays. Within these cities, expatriates often inhabit the same spaces, buildings and neighbourhoods as former colonialists, and "such active infrastructural renewal provides a material assemblage facilitating the repetition of colonial routines" (ibid., p.6). 
Emblematic of such a renewal of colonial 'rhythms and routines' are social clubs, similarly central to contemporary expatriate communities as they were to colonial societies (Leonard 2010a; Coles \& Walsh 2010; Beaverstock 2002, 2011). Expatriate clubs serve social and professional functions; Beaverstock (2011, p.725) finds that in Singapore they are essentially "an extension of downtown Commerce". Often exclusive spaces, clubs also remain key for social boundary marking, including the reproduction of Imperial subjectivities. As Leonard (2010c, p.1255) finds in the case of Hong Kong, while now open to all nationalities, Imperialist attitudes and a strong sense of racial difference are often actively sustained through the club's organisation and management, and the routines of everyday club life (cf. Fechter 2007; Coles \& Walsh 2010).

Knowles (2005) suggests that Empire also survives in the 're-making' of whiteness through specific social mechanisms, including spatial movements ranging from the global geometries of migration to expatriates' local navigation and use of postcolonial cities. Accordingly, expatriates' daily lives in Indonesia involve a constant negotiation and management of public space inherently bound up with whiteness and the constant anxiety to avoid the 'gaze of the Other' (Fechter 2005, 2007, 2010). Generally, the functioning of whiteness differs by context, is unstable, and intersects with other dimensions like gender and class (Walsh 2010). Yet, in the 'West' whiteness is usually treated as the racial norm and white people do not expect to be racially visible, let alone primarily defined by their 'race' (cf. Dyer 1997; Bonnett 2000). This in itself is thus an uncomfortable experience; moreover, Fechter's (2005) work suggests that expatriates perceive being read as not constituting the racial norm, even as 'deficient' by a group commonly assumed to be 'lesser', as an illegitimate claim to power by Indonesians. While whiteness functions as an often unreflectively assumed capital in the global economy, its effects in other contexts can just as easily involve the disconcerting "sense of being deprived of a normative and structurally invisible position" (Lundström 2014, p.6).

National identities have been found to gain heightened importance upon migration, and expatriates are no exception; often bound up with whiteness, 
nationality is routinely enacted and consciously embodied (O'Reilly 2000; Fechter 2007; Klekowski von Koppenfels 2014; Walsh 2006a, 2010, 2012; Leonard 2010ab). In previously colonised contexts, although not unchallenged, expatriate national identities can still be grounded in historical notions of racial and cultural superiority versus the local other (Leonard 2008; Walsh 2012). This expresses itself in everyday racisms and wider discourses of cultural difference that prescribe a broad range of strategies to 'manage' the local in daily life, including careful regimes around domestic hygiene and food (Fechter 2007, 2010; Armbruster 2010; Leonard 2010a; Coles \& Walsh 2010). While expatriate communities often form around class and nationality, an imagined 'West' figures similarly strongly in expatriate identities (Fechter 2007; Korpela 2010). For instance Legget (2010) observes that in Jakarta nationality often matters less than a collective Imperial identification as 'Westerners'. Likewise, performances of cosmopolitan attitudes and middle-class status can be equally central (Hindmann 2009b). Hindmann (2009a) observes that in Kathmandu expatriates and national elites produce themselves as cosmopolitan subjects through a form of ritual exchange of often-commodified culture that neither is expected to embody. Often 'traveling in Orientalism', both collaborate to codify difference in a way that renders an essentialised identity as something that others have and which they consume while sharing in a 'global' language about modernity and progress (Hindmann 2009a).

Of course, expatriate lives are not simply continuations of Imperial ones; rather, contemporary migrants engage in a continuous re-working but also a challenging, rather than a simple inheritance of their heritage (Leonard 2008; Lester 2012). Leonard (2008, p.57) points to British migrants in Hong Kong at pains to locate themselves outside narratives of expatriation and to "negotiate identities [that] counter the hegemony of discourses of white and national privilege" (cf. Walsh 2010). Farrer (2010) traces the diversity of narratives expatriates employ to write themselves into the 'global city' Shanghai. While the colonial is a salient part of the resources they draw on, their narratives cannot be reduced to the neo-colonial. Farrer (2010) also points to the extended periods of limbo expatriates find themselves in, remaining an assumedly inassimilable 
category, politically and also racially, even after decades in the country. Generally, it needs to be explored further why individuals relate to or contest the label expatriate. Many privileged migrants do not want to lead lives reminiscent of colonial pasts (Leonard 2008; Walsh 2010); yet, a certain type of 'expatriate community' nevertheless remains a structural feature of societies in the global South.

\section{New directions in expatriate research: The expatriate as a category of practice}

This article discusses literature that examines expatriate migration, mainly to the global South, and largely shares a critical, often postcolonial perspective. Authors like Fechter (2007) and Leonard (2010a) have discussed the category's controversial nature and noted the tension inherent in the challenge of studying the concept without reproducing a reified understanding of it. This recognition remains critical as scholarship on expatriate migration can run the risk of further reifying and essentialising the category, thereby reproducing rather than merely analysing privilege in migration. In other words, to disambiguate expatriates from (im)migrants is at some level to conceal the fact that expatriates are indeed (im)migrants. They differ from other migrants most pointedly in their embodiment of interlinking forms of privilege and their access to various sorts of capital that have purchase across a wide range of settings. As Croucher (2012, p. 4) argues:

Greater terminological precision will be key to moving this field of study forward, and an important step in that process lies in unmasking how privilege itself resides in and is perpetuated by the multiplicity of terms other than 'immigrant' employed to characterize privileged mobility.

Instead of developing new typologies we might want to spend more time critically examining and dissecting existing ones, and considering the systems and processes that create stratification in migration.

To this end, it is useful to draw on Brubaker and Cooper's (2000, p.4) distinction between scholarly 'categories of analysis' and 'categories of practice' as 
"categories of everyday social experience, developed and employed by ordinary social actors". Difficulty arises from the fact that many categories (e.g. 'race' or identity) are both categories of analysis and practice, and their interchangeable use often entails an "uncontrolled conflation of [...] folk and analytical understandings" (ibid. p.6). In other words, there is a danger that academic uses of terms might reproduce, even reinforce the reification of social categories (Brubaker 2013). Scholars need to be critical and self-reflexive in how they handle concepts, and aware of what assumptions they accept implicitly or explicitly. This especially applies when adopting categories of practice for purposes of analysis that are "riddled with ambiguity, riven with contradictory meanings, and encumbered by reifying connotations", as the case for the 'expatriate' (Brubaker \& Cooper 2000, p.34). Expatriate should thus not be treated as a 'category of analysis' available as a straightforward a priori conceptual frame. Instead, scholarship needs to further turn the construction of the category itself into the object of analysis, as illustrated by Fechter (2007), Leonard (2010a) and Walsh (2014). Rather than assuming expatriate to denote a certain type of migrant, for example a highly skilled one, 'expatriate' in its myriad appearances and meanings needs to be further opened up for investigation; conceptualized and analysed as a category of practice that amongst other things expresses and performs a certain migrant subjectivity and describes certain locations or aspirations to position oneself within various local and global political and economic formations. At the heart of such processes lie complex configurations of racialisation, class, nationality, and gender, which are inherently related to the various instabilities and ambiguities of the notion expatriate itself. These ultimately render it so problematic as a pre-given 'category of analysis'. Yet, the exact processes through which the expatriate emerges as a 'category of practice' need further exploring, and some areas have particular salience for future research.

First, how do different 'types' of migrants, amongst them the 'expatriate', emerge as contingent and often precarious products of social, political, economic and cultural processes and institutions? Besides some indicative findings (e.g. Walsh 2010, 2012) little is known about how the conceptual boundaries of the 
expatriate, against for instance the 'immigrant', are maintained in everyday life, through economic relations, in institutional settings and wider social discourses. Within migration studies, there is an urgent need to further explore what has retained the expatriate as a discrete category in popular imagination but also in scholarship; whether and how this category is challenged from within or 'defended' against other less privileged migrants; who is excluded from the category, and how these boundaries are shifting within specific localities but also more generally. For these purposes especially, it is necessary to also turn to the experiences and understandings of expatriates' constitutive 'Others', be it locals or other migrants. How do they experience, make sense of and negotiate their interactions, relations with and differences from those migrants called expatriates. So far, the experiences or voices of host country nationals and other migrants are virtually absent from scholarship (Fechter \& Walsh 2010). Given that the expatriate is an inherently relational identity, defined as much through the practices of migration that it is as through those that it is not, this is an important lacuna.

Second, migrant lives are characterised by 'dwelling in mobility', by travelling in transnational circuits and by processes of translation (Clifford 1997; Walsh 2011). Scholarship needs to further explore specific 'places' (re-) constructed by expatriate migration, to understand it as a situated and contextual phenomenon; yet, there is also a need for more comparative work (Walsh 2014); for work to follow migrants' routes, trace the discourses and networks they are embedded in and webs they employ and spin (Lester 2012); and crucially to ask how these are related to the global power geometries of globalising capital, neoliberal governmentality and the histories of colonialism and Empire? Additionally, it should be further considered how translation works in these processes. For instance, Lundström (2014) notes that the shifting and travelling formations of whiteness in contemporary transnational migration, their translations and reformulations continue to be a promising yet largely overlooked topic of analysis. Equally, not all 'expatriates' can lay claims to the privileges of whiteness or transport these privileges across contexts. Exploring the central role of racialisation in expatriate migration also means becoming more sensitive to non- 
white experiences and negotiations of the expatriate. Additionally, research has predominantly explored the expatriate as an Anglophone notion. Little is known about whether and how the category translates in non-Anglophone contexts, how migrants for whom English is not a native language relate to it and whether and how expatriate spaces function as multilingual spaces beyond the Anglophone.

Not only does research on expatriates need to be further tied in with research on less privileged forms of migration; as argued by Fechter and Walsh (2010), existing migration studies, predominantly focused on less privileged migrants, may need to be revisited and reformulated in its light. Postcolonial approaches address Imperial and colonial legacies and investigate the mechanisms that sustain colonial relations of power in the present, often paying particular attention to the politics of representation, knowledge and identity formation. Work on expatriates has engaged with postcolonial and critical race theories to produce nuanced analyses, for instance of the making and privileging of whiteness and masculinity within expatriate settings. Informed by these approaches, research on expatriates has accounted for historically rooted global structures of power and inequality that migrants move within. These avenues should be explored further; especially as such dimensions are arguably neglected in mainstream migration scholarship, which too often relies on methodologically nationalist perspectives and models (Glick-Schiller 2009, 2010; Castles 2007). Moreover, attending to more alongside less privileged forms of movement may provide avenues for analysing the increasing bifurcation of migration regimes, or what Castles (2007, p.360) has called "the hierarchisation of the right to migrate [which] can be seen as a new form of transnational racism". Besides further employing postcolonial critiques, migration studies would benefit from engaging approaches that offer critical understandings of globalisation, of neoliberal projects of social and economic restructuring and of neoliberalism as global governance strategy (e.g. Massey 2005; Hall 2011; Harvey 2001, 2006; Brown 2015). This sort of critical work offers expatriate studies further productive ways to understand migration in the context of wider power relations; and put in dialogue with postcolonial perspectives it can address the interworking of on- 
going coloniality, globalising neoliberal capitalism and (privileged) migration. Generally, these approaches enable a critical reading of the socio-economic conditions that underpin migrant identities as much as the material conditions of migration. Similarly, they demand a dialectical analysis of migrant dynamics that overcomes categorical fixities, considers them in their interrelations, and historicises transnational practices. As shown throughout this review, drawing on such resources enables a critical, reflexive and nuanced reading of the expatriate as a category of practice; it allows investigating its production, performance and resistance, the social relations it organises, the functions it fulfils, the borders it draws in diasporic space and the particular in- and exclusions it narrates but also reproduces in the context of larger political and economic formations.

\section{Bibliography}

Amit, V. (Ed.). (2011). Going First Class? New Approaches to Privileged Travel and Movement. Oxford: Berghahn Books.

Armbruster, H. (2010). "Realising the Self and Developing the African": German Immigrants in Namibia. Journal of Ethnic and Migration Studies, 36(8), pp. 1229-1246.

Beaverstock, J. V. (2002). Transnational elites in global cities: British expatriates in Singapore's financial district. Geoforum, 33(4), pp. 525-538.

Beaverstock, J. V. (2005). Transnational elites in the city: British highly-skilled inter-company transferees in New York city's financial district. Journal of Ethnic and Migration Studies, 31(2), pp. 245-268.

Beaverstock, J. V. (2011). Servicing British Expatriate "Talent” in Singapore: Exploring Ordinary Transnationalism and the Role of the "Expatriate" Club. Journal of Ethnic and Migration Studies, 37(5), pp. 709-728.

Benson, M. (2014). The British in Rural France: Lifestyle Migration and the Ongoing Quest for a Better Way of Life. Manchester: Manchester University Press.

Benson, M. and O’Reilly, K. (2009). Lifestyle Migration. Farnham, England; Burlington, VT: Ashgate. Bickers, R. (Ed.). (2010). Settlers and Expatriates: Britons Over the Seas. Oxford; New York: OUP Oxford.

Bonnett, A. (2000). White Identities: Historical and International Perspectives. Harlow, England; New York: Prentice Hall.

Brown, W. (2015). Undoing the Demos: Neoliberalism's Stealth Revolution. New York: Zone Books. Brubaker, R. (2013). Categories of analysis and categories of practice: a note on the study of Muslims in European countries of immigration. Ethnic and Racial Studies, 36(1), pp. 1-8. 
Brubaker, R. and Cooper, F. (2000). Beyond "identity." Theory and Society, 29, pp. 1-47.

Castles, S. (2007). Twenty-First-Century Migration as a Challenge to Sociology. Journal of Ethnic and Migration Studies, 33(3), pp. 351-371.

Clifford, J. (1997). Routes : travel and translation in the late twentieth century. Cambridge, Mass ; London: Harvard University Press.

Cohen, E. (1977). Expatriate Communities. Current Sociology, 24(3), pp. 5-90.

Cole, N. D. (2012). Expatriate accompanying partners: the males speak. Asia Pacific Journal of Human Resources, 50(3), pp. 308-326.

Coles, A., and Fechter, A. M. (Eds.). (2008). Gender and Family Among Transnational Professionals. London, New York: Routledge.

Coles, A., and Walsh, K. (2010). From "Trucial State" to "Postcolonial” City? The Imaginative Geographies of British Expatriates in Dubai. Journal of Ethnic and Migration Studies, 36(8), pp. 1317-1333.

Conradson, D., and Latham, A. (2005). Friendship, networks and transnationality in a world city: Antipodean transmigrants in London. Journal of Ethnic and Migration Studies, 31(2), pp. 287305.

Cranston, S. (2014). Reflections on doing the Expat Show: performing the Global Mobility Industry. Environment and Planning A, 46(5), pp.1124-1138.

Croucher, S. (2012). Privileged Mobility in an Age of Globality. Societies, 2(4), pp. 1-13.

Dabic, M., González-Loureiro, M., and Harvey, M. (2013). Evolving research on expatriates: what is “known” after four decades (1970-2012). The International Journal of Human Resource Management $0(0)$, pp. 1-22.

Dyer, R. (1997). White: Essays on Race and Culture. London ; New York: Routledge.

Farrer, J. (2010). "New Shanghailanders" or "New Shanghainese”: Western Expatriates' Narratives of Emplacement in Shanghai. Journal of Ethnic and Migration Studies 36(8), pp. 1211-1228.

Favell, A. (2008). Eurostars and Eurocities. Malden, MA: Wiley-Blackwell.

Fechter, A.M. (2005). The "Other" stares back Experiencing whiteness in Jakarta. Ethnography 6(1), pp. 87-103.

Fechter, A. M. (2007). Transnational Lives: Expatriates in Indonesia. Aldershot, Hants, England; Burlington, VT: Ashgate.

Fechter, A. M. (2008). From "Incorporated Wives" to "Expat Girls": a New Generation of Expatriate Women? In A. Coles \& A.-M. Fechter (Eds.), Gender and Family among Transnational Professionals. London: Routledge, pp. 193-209.

Fechter, A. M. (2010). Gender, Empire, Global Capitalism: Colonial and Corporate Expatriate Wives. Journal of Ethnic and Migration Studies 36(8), pp. 1279-1297.

Fechter, A. M. (2012a). The Personal and the Professional: Aid workers' relationships and values in the development process. Third World Quarterly 33(8), pp. 1387-1404.

Fechter, A. M. (2012b). "Living Well” while "Doing Good”? (Missing) debates on altruism and professionalism in aid work. Third World Quarterly 33(8), pp. 1475-1491.

Fechter, A. M. (2013). The Personal and the Professional in Aid Work. London: Routledge. 
Fechter, A. M., and Walsh, K. (2010). Examining “Expatriate” Continuities: Postcolonial Approaches to Mobile Professionals. Journal of Ethnic and Migration Studies 36(8), pp. 1197-1210.

Financial Times Lexicon. (n.d.). Expatriate Definition. Retrieved July 16, 2015, from [http://lexicon.ft.com/Term?term=expatriate].

Findlay, A. M. (1995). Skilled transients: the invisible phenomenon? In: Cohen, R., (Ed.), The Cambridge Survey of World Migration. Cambridge: Cambridge University Press, pp. 515-522.

Findlay, Li, F.L.N., Jowett, A.J., and Skeldon, R. (1996). Skilled International Migration and the Global City. Transactions of the Institute of British Geographers 21(1), pp. 49-61.

Glick Schiller, N. (2009). A Global Perspective on Migration and Development. Social Analysis, 53(3), pp. 14-37.

Glick Schiller, N. (2010). A global perspective on transnational migration: Theorising migration without methodological nationalism. In: Bauböck, R. and Faist, T., (Eds.), Diaspora and Transnationalism: Concepts, Theories and Methods. Amsterdam: Amsterdam University Press, pp. 109-129.

Green, N. L. (2009). Expatriation, Expatriates, and Expats: The American Transformation of a Concept. The American Historical Review 114(2), pp. 307-328.

Green, N. L. (2014). The Other Americans in Paris: Businessmen, Countesses, Wayward Youth, 18801941. Chicago: University of Chicago Press.

Hall, S. (2011). The Neo-Liberal Revolution. Cultural Studies 25(6), pp. 705-728.

Harrison, D. A., Shaffer, M. A., and Bhaskar-Shrinivas, P. (2004). Going places: Roads more and less travelled in research on expatriate experiences. In Research in Personnel and Human Resources Management 23, pp. 199-247.

Harvey, D. (2001). Spaces of Capital: Towards a Critical Geography. Edinburgh: Edinburgh University Press.

Harvey, D. (2006). Spaces of Global Capitalism: A Theory of Uneven Geographical Development. London; New York, NY: Verso.

Harvey, W. S. (2008). The social networks of British and Indian expatriate scientists in Boston. Geoforum 39(5), pp. 1756-1765.

Harvey, M., and Moeller, M. (2009). Expatriate mangers: A historical review. International Journal of Management Reviews 11(3), pp. 275-296.

Hayes, M. (2015). Moving South: The Economic Motives and Structural Context of North America's Emigrants in Cuenca, Ecuador. Mobilities 10(2), pp. 267-284.

Hindman, H. (2009a). Cosmopolitan Codifications: Elites, Expatriates, and Difference in Kathmandu, Nepal. Identities 16(3), pp. 249-270.

Hindman, H. (2009b). Shopping in the Bazaar/Bizarre Shopping: Culture and the Accidental Elitism of Expatriates in Kathmandu, Nepal. The Journal of Popular Culture 42(4), pp. 663-679.

Hindman, H., \& Fechter, A. M. (Eds.). (2010). Inside the Everyday Lives of Development Workers: The Challenges and Futures of Aidland. Sterling, VA: Kumarian Press.

King, R., Warnes, T., and Williams, A. M. (2000). Sunset Lives: British Retirement Migration to the Mediterranean. Oxford: Berg. 
Klekowski von Koppenfels, Amanda. (2014). Migrants or Expatriates? Houndmills, Basingstoke, Hampshire; New York: Palgrave Macmillan.

Knowles, C. (2005). Making Whiteness: British Lifestyle Migrants in Hong Kong. In C. Alexander \& C. Knowles (Eds.), Making Race Matter: Bodies, Space and Identity. Houndmills, Basingstoke, Hampshire ; New York: Palgrave Macmillan, pp. 90-110.

Knowles, C., and Harper, D. (2010). Hong Kong: Migrant Lives, Landscapes, and Journeys. Chicago; London: University Of Chicago Press.

Korpela, M. (2010). A Postcolonial Imagination? Westerners Searching for Authenticity in India. Journal of Ethnic and Migration Studies 36(8), pp. 1299-1315.

Kothari, U. (2006). Spatial practices and imaginaries: Experiences of colonial officers and development professionals. Singapore Journal of Tropical Geography 27(3), pp. 235-253.

Leggett, W. H. (2010). Institutionalising the Colonial Imagination: Chinese Middlemen and the Transnational Corporate Office in Jakarta, Indonesia. Journal of Ethnic and Migration Studies 36(8), pp. 1265-1278.

Lehmann, A. (2014). Transnational Lives in China: Expatriates in a Globalizing City. New York: Palgrave Macmillan.

Leinonen, J. (2012). Invisible Immigrants, visible expats? Americans in Finnish discourses on immigration and internationalization. Nordic Journal of Migration Research 2(3), pp. 213-223.

Leonard, P. (2008). Migrating identities: gender, whiteness and Britishness in post-colonial Hong Kong. Gender, Place \& Culture 15(1), pp. 45-60.

Leonard, P. (2010a). Expatriate Identities in Postcolonial Organizations. Farnham, Surrey ; Burlington, VT: Ashgate.

Leonard, P. (2010b). Old Colonial or New Cosmopolitan? Changing White Identities in the Hong Kong Police. Social Politics: International Studies in Gender, State \& Society 17(4), pp. 507535 .

Leonard, P. (2010c). Work, Identity and Change? Post/Colonial Encounters in Hong Kong. Journal of Ethnic and Migration Studies 36(8), pp. 1247-1263.

Lester, A. (2012). Foreword. In: Fechter, A.M., and Walsh, K. (Eds.), The new expatriates: postcolonial approaches to mobile professionals. London; New York: Routledge, pp. 1-8.

Lloyd, J. (2014). Bodies over borders: The sized body and geographies of transnationalism. Gender, Place \& Culture 21(1), pp. 123-131.

Lloyd, J., and Hopkins, P. (2015). Using interviews to research body size: methodological and ethical considerations: Using interviews to research body size. Area 47(3), pp. 305-310.

Luibhéid, E. (2004). Heteronormativity and immigration scholarship: A call for change. GLQ: A Journal of Lesbian and Gay Studies 10(2), pp. 227-235.

Lundström, C. (2014). White Migrations: Gender, Whiteness and Privilege in Transnational Migration. Houndmills, Basingstoke, Hampshire; New York, NY: Palgrave Macmillan.

Manalansan, M. F. (2006). Queer Intersections: Sexuality and Gender in Migration Studies. International Migration Review 40(1), pp. 224-249.

Massey, D. (2005). For Space. London; Thousand Oaks: SAGE Publications. 
Meier, L. (2015). Migrant Professionals in the City: Local Encounters, Identities, and Inequalities:

Local Encounters, Identities and Inequalities. New York: Routledge.

O’Reilly, K. (2000). The British on The Costa Del Sol. New York: Routledge.

Redfield, P. (2012). The Unbearable Lightness of Expats: Double Binds of Humanitarian Mobility. Cultural Anthropology 27(2), pp. 358-382.

Rogaly, B., and Taylor, B. (2010). “They called them Communists then...what d'you call 'em now?... Insurgents?" Narratives of British military expatriates in the context of the new imperialism. Journal of Ethnic and Migration Studies 36(6), pp. 1335-1351.

Salt, J. (1988). Highly-skilled international migrants, careers and internal labour markets. Geoforum; Journal of Physical, Human, and Regional Geosciences 19(4), pp. 387-399.

Scott, S. (2004). Transnational exchanges amongst skilled British migrants in Paris. Population, Space and Place 10(5), pp. 391-410.

Scott, S. (2006). The Social Morphology of Skilled Migration: The Case of the British Middle Class in Paris. Journal of Ethnic and Migration Studies 32(7), pp. 1105-1129.

Sriskandarajah, D., and Drew, C. (2006). Brits abroad: mapping the scale and nature of British emigration. London: Institute for Public Policy Research.

Stone, I., and Stubbs, C. (2007). Enterprising expatriates: lifestyle migration and entrepreneurship in rural southern Europe. Entrepreneurship \& Regional Development 19(5), pp. 433-450.

United Nations Department of Economic and Social Affairs (1998). Recommendations on Statistics of International migration Revision 1. New York: United Nations. Retrieved July 20, 2015, from http://unstats.un.org/unsd/demographic/sconcerns/migration/migrmethods.htm

van Bochove, M., and Engbersen, G. (2013). Beyond Cosmopolitanism and Expat Bubbles: Challenging Dominant Representations of Knowledge Workers and Trailing Spouses. Population, Space and Place 21(4), pp. 295-309.

Walsh, K. (2006a). “Dad says I”m tied to a shooting star!' Grounding (research on) British expatriate belonging. Area 38(3), pp. 268-278.

Walsh, K. (2006b). British expatriate belongings: mobile homes and transnational homing. Home Cultures 3(2), pp. 123-144.

Walsh, K. (2007). “It got very debauched, very Dubai!” Heterosexual intimacy amongst single British expatriates. Social \& Cultural Geography 8(4), pp. 507-533.

Walsh, K. (2010). Negotiating migrant status in the emerging global city: Britons in Dubai. Encounters 2 , pp. 235-255.

Walsh, K. (2011). Migrant masculinities and domestic space: British home-making practices in Dubai. Transactions of the Institute of British Geographers 36(4), pp. 516-529.

Walsh, K. (2012). Emotion and migration: British transnationals in Dubai. Environment and Planning D: Society and Space 30(1), pp. 43-59.

Walsh, K. (2014). Placing Transnational Migrants through Comparative Research: British Migrant Belonging in Five GCC Cities. Population, Space and Place 20(1), pp. 1-17. 
Willis, K., and Yeoh, B. (2008). "Coming to China Changed My Life": Gender Roles and Relations among Single British Migrants. In A. Coles \& A.-M. Fechter (Eds.), Gender and Family Among Transnational Professionals. London: Routledge, pp. 211-232.

Yeoh, B. S. A., and Willis, K. (2005a). Singaporean and British transmigrants in China and the cultural politics of “contact zones.” Journal of Ethnic and Migration Studies 31(2), pp. 269-285.

Yeoh, B. S. A., and Willis, K. (2005b). Singaporeans in China: transnational women elites and the negotiation of gendered identities. Geoforum 36(2), pp. 211-222.

Yeoh, B. S., and Khoo, L.-M. (1998). Home, work and community: Skilled international migration and expatriate women in Singapore. International Migration 36(2), pp. 159-186. 